УДК 299.27

DOI 10.52575/2712-746X-2021-46-4-700-708

\title{
Литературно-мифологические архетипы насилия, мира и милосердия в доисламской поэзии и прозе
}

\author{
${ }^{1}$ Борисовский А.В., ${ }^{2}$ Резник С.В. \\ ${ }^{1}$ Белгородский государственный институт искусств и культуры, \\ Россия, 308033, г. Белгород, ул. Королёва, 7 \\ ${ }^{2}$ Белгородский государственный национальный исследовательский университет, \\ Россия, 308015, г. Белгород, ул. Победы, 85 \\ E-mail: reznik@bsu.edu.ru; borisovskiy_a@bsu.edu.ru
}

\begin{abstract}
Аннотация. В рамках реализации поставленной цели рассмотрена проблема реконструкции архетипов насилия, мира и милосердия, которые легли в основу идеологических конструктов религии ислама. Автор статьи ставит задачу извлечь архетипическую основу, растворенную в арабо-семитской (доисламской) мифологии, ставшую частью священных текстов ислама. Проведенный анализ арабо-семитской мифологии, которая отразилась в арабском языческом пантеоне, мифах и легендах, позволил реконструировать литературно-мифологические сюжетные архетипы доисламской арабской поэзии и прозы. Автор приходит к выводу о том, что архетипы насилия, мира и милосердия, сформированные арабской мифологией, нашли свое отражение в доисламской поэзии и прозе, прославлявших племенной патриотизм доисламских аравийских племен и ценности родоплеменного общества. Исламская теология, ориентированная на универсализм религии ислама, восприняла литературно-мифологические архетипы насилия, мира и милосердия доисламской поэзии и прозы и переработала их в соответствии с потребностями новой монотеистической религии, выходящей далеко за рамки этики племенного патриотизма.
\end{abstract}

Ключевые слова: арабо-семитская доисламская мифология, джахилийя, касыда, жанры доисламской арабской поэзии, хутба, шаиры, хатибы.

Для цитирования: Борисовский А.В., Резник С.В. 2021. Литературно-мифологические архетипы насилия, мира и милосердия в доисламской поэзии и прозе. NOMOTHETIKA: Философия. Социология. Право, 46(4): 700-708. DOI: 10.52575/2712-746X-2021-46-4-700-708

\section{Literary and Mythological Plot Archetypes of Violence, Peace and Mercy in Pre-Islamic Poetry and Prose}

\author{
${ }^{1}$ Andrey V. Borisovskiy, ${ }^{2}$ Sergey V. Reznik, \\ ${ }^{1}$ Belgorod State Institute of Arts and Culture, \\ 7 Koroleva St, Belgorod 308033, Russian Federation \\ ${ }^{2}$ Belgorod National Research University, \\ 85 Pobedy St, Belgorod 308015, Russian Federation \\ E-mail: reznik@bsu.edu.ru; borisovskiy_a@bsu.edu.ru
}

\begin{abstract}
As part of the implementation of this goal, the problem of reconstruction of the archetypes of violence, peace and mercy, which formed the basis of the ideological constructs of the religion of Islam, is considered. The author of the article sets the task of extracting the archetypal basis, dissolved in the Arab-Semitic (pre-Islamic) mythology, which has become part of the sacred texts of Islam. The author's analysis of the Arab-Semitic mythology, which was reflected in the Arab pagan pantheon, myths and legends, made it possible to reconstruct the literary and mythological archetypes of pre-Islamic Arabic poetry and prose. The author of the article concludes that the archetypes of violence, peace and mercy, formed by Arab mythology, were reflected in pre-Islamic poetry and prose, glorifying the tribal patriotism of pre-Islamic Arabian tribes and the values of tribal society. Islamic theology, focused on the
\end{abstract}


universalism of the religion of Islam, adopted the literary and mythological plot archetypes of violence, peace and mercy of pre-Islamic poetry and prose and reworked them in accordance with the needs of the new monotheistic religion, going far beyond the ethics of tribal patriotism.

Keywords: peace and mercy, Arab-Semitic pre-Islamic mythology, jahiliyah, qasida, genres of preIslamic Arabic poetry, khutba, shaira, khatib.

For citation: Borisovskiy A.V., Reznik S.V. 2021. Literary and Mythological Plot Archetypes of Violence, Peace and Mercy in Pre-Islamic Poetry and Prose. NOMOTHETIKA: Philosophy. Sociology. Law, 46(4): 700-708 (in Russian). DOI: 10.52575/2712-746X-2021-46-4-700-708

\section{Введение}

В данной статье мы обращаемся к исследованию архетипов насилия, мира и милосердия в арабо-семитской мифологии и генезисе ислама. Наша задача заключается в реконструкции архетипов насилия и ненасилия, которые, по нашему мнению, легли в основу идеологических конструктов религии ислама, извлечении архетипической основы, растворенной в арабо-семитской (доисламской) мифологии, ставшей частью священных текстов ислама. Ключевым для реконструирования архетипической основы концептов насилия, мира и милосердия в доисламской арабо-семитской мифологии является понятие «культурный архетип». В нашем исследовании мы применяем определение «культурного архетипа» К. Юнга, для которого мифология была выражением универсального человеческого коллективного бессознательного [Юнг, 1991, с. 32].

Актуальность обращения к доисламским традициям и верованиям Аравии в контексте генезиса ислама уже к середине XX столетия была признана как зарубежными (Г.Э. фон Грюнебаум [1986] Ф.Э. Петерс [Peters, 1994], А. Массэ [2007],), так и отечественными востоковедами (П.А. Грязневич [1984], М.Б. Пиотровский [1984], Е.А. Резван [1984]). Британский арабист У.М. Уотт в исследовании, посвященном мединскому периоду биографии основателя ислама, относительно доисламской истории Аравии отметил: «Серьезным пробелом является то, что изучение жизни в доисламской Аравии отстает от изучения достижений социальной антропологии... знакомство с доисламской средой является необходимой основой для понимания социальных реформ Мухаммада» [Уотт, 2007, c. 6].

К числу важных выводов, сделанных отечественными исследователями, следует отнести прежде всего рассмотрение ислама как закономерного этапа в развитии форм религиозного сознания жителей Внутренней Аравии [Грязневич, 1984], установление связи между религиозно-реформаторской деятельностью основателя ислама и пророческим движением кахинов, сложившимся в Аравии VII в. [Пиотровский, 1984, с. 25], подтверждение положения о том, что ритуальные запреты ислама на употребление вина и свинины, требование поклонения Каабе имеют истоки в языческих верованиях северо-западной и южно-семитской групп [Шифман, 1984, с. 41], установление связи ранней исламской терминологии с доисламскими традициями, которые были трансформированы в свете монотеистических идей [Резван, 1984, с. 65].

Еще в доисламскую эпоху племенной социум в представлениях его членов выступал единственным гарантом сохранения традиционных ценностей. Представители других племен считались чужаками, поэтому находились вне племенных законов. По нашему мнению, здесь, согласно концепции архетипов коллективного бессознательного К.Г. Юнга, проявляется архетип Тень. Функционирование последнего происходит путем проецирования отрицаемых и подавляемых в себе качеств на других, санкционируя насилие в отношении тех, кто не является сородичем, соплеменником, носителем родовых, племенных традиций. 
Как отмечает отечественный исследователь К.П. Матвеев, «общепризнанные арабские добродетели объединялись понятием "муравва" (обладание качествами мужчины), включавшим такие достоинства, как воинская доблесть, щедрость и верность племенным традициям. Например, закон мести. Кровная месть была и сохраняется в наше время с определенными модификациями. Этот обычай был естественен в патриархальном обществе с его принципом родовой коллективной ответственности за проступки каждого соплеменника. Кровная месть совершалась, дабы возместить ущерб роду и родовому обществу, т. е. одновременно социальной и религиозной ячейке» [Матвеев, 2005, с. 57]. Следует отметить, что обычай кровной мести среди арабов доисламской эпохи служил одним из средств регулирования социальных отношений, защиты жизни индивида или социальной группы в социумах, существующих в условиях отсутствия институтов государственной власти. Обычай кровной мести требовал обязательного возмездия за убийство или нанесение увечий.

В коранической этике и правовой доктрине ислама отсутствует понятие кровной мести, что указывает на то, что последняя является языческим обычаем, не имеющим никакого отношения к религии ислама. «О те, которые уверовали! Предписано вам возмездие за убитых: свободный - за свободного, и раб - за раба, и женщина - за женщину. А кому будет прощено что-нибудь его братом, то - следование по обычаю и возмещение ему во благе» (2: 178) [Коран]. Российский религиозный деятель, исламский ученый, имамхатыб московской Мемориальной мечети Ш.Р. Аляутдинов ссылается на другой перевод аята 179 Суры 2 «аль-Бакара»: «И для вас, обладатели разума, в кысасе (в наказании, соизмеримом со степенью тяжести преступления) - жизнь, возможно вы будете набожны [справедливы в вынесении смертного приговора, когда преднамеренность убийства не вызывает сомнений]» ${ }^{1}$. Как видим, в данном переводе вместо «возмездие» используется термин «кылас» - «это не месть, а наказание, равноценное урону, нанесенному преступными действиями (равное, соизмеримое с тяжестью преступления)» [там же].

Из вышесказанного следует вывод о том, что вероучение ислама, искореняя языческий обычай кровной мести, переводило насилие в сферу сакрального, т. е. насилие, в данном случае возмездие для преступников, осуществлялось в рамках божественного закона и ограничивалось рамками решений, выносимых шариатскими судами. Смысл насилия, применяемого теократическим государством, каковым являлся Арабский халифат, заключался в том, чтобы донести до населения идею о том, что для преступника, в случае если факт его вины неоспорим, наказание неотвратимо.

\section{Влияние географической среды, природно-климатических и социально-экономических условий Аравии на доисламскую мифологию}

Естественно, что географическая среда, природно-климатические и социальноэкономические условия проживания жителей Аравии оказывали серьезное влияние на их кругозор и мировоззрение. Религиозно-мифологические представления арабов-язычников складывались под воздействием сложных природно-климатических условий Аравии. Недостаток пастбищных угодий для арабов-бедуинов приводил к голоду, болезням и в конечном счете к вымиранию. Арабские племена вынуждены были вести кровопролитные войны и покидать пределы Аравии. Сопредельные государства постоянно испытывали набеги со стороны кочевников, которые не только подвергали разорению приграничные территории, но и проникали в центральные части, нанося ощутимый ущерб хозяйственной жизни населения данных регионов [Фильштинский, 1977].

1 Аляутдинов Ш. Кровная месть в Исламе. URL: https://umma.ru/krovnaja-mest-v-islame/ (дата обращения: 15.09.21). 
Арабские племена, по свидетельству исторических источников, постоянно находились в состоянии войны как со своими дальними соседями, так и с ближайшим окружением. Естественно, что сложившиеся социально-экономические условия того времени вынуждали кочевое население Аравии следовать такой стратегии ради выживания. Постоянные войны, которые велись между бедуинами-кочевниками и оседлым населением Аравийского полуострова, не только воспитали в арабах-бедуинах особые черты характера, которые соответствовали образу воина-кочевника, но и вынуждали оседлое население Аравии всегда быть готовым защищать свою жизнь и имущество с оружием в руках.

Воинственность арабов отразилась и в их доисламской мифологии. В частности, многие божества языческого пантеона наделялись военными функциями, как например, божество мужского рода Зу-ль-Халаса (араб. идол войны). Культ данного божества отправлялся в Мекке и Табале. В Табале было расположено святилище данного божества, который почитался в виде белокаменного идола с высеченной на нем короной. Внутри самого святилища располагалась статуя воина, вооруженного луком. Точные функции данного языческого божества не известны, однако его название говорит само за себя. Следует отметить, что с приходом на Аравийский полуостров ислама, данное святилище было разрушено, а его идол был переделан в порог, построенной на его месте мечети.

Другим примером является древнеарабская богиня неба и дождя Аллат, aл-Лат (араб. богиня). В доисламские времена некоторыми этническими группами почиталась как богиня солнца, однако наиболее распространенным был культ почитания Аллат как богини Венеры, поэтому она отождествлялась с древнегреческой богиней Афиной (Уранией). Очевидно, почиталась в качестве владычицы туч и молний, а также связывалась с войной. В Набатее и Пальмире Аллат отождествлялась с древнегреческой богиней Афиной. Сохранились ее изображения как богини-воительницы с копьем, в шлеме, иногда восседающей на троне в окружении львов [Мифологический словарь, 1991].

Из вышесказанного видно, что проблемы войны и мира занимали в древнеарабском, особенно бедуинском, обществе исключительно важное место. Свидетельством тому являются не только религиозные и мифологические образы и сюжеты, но и древнеарабский фольклорный жанр, запечатленный в пословицах и поговорках. Постоянные межплеменные и междоусобные войны, которыми изобиловала история доисламской Аравии, способствовали частому упоминанию оружия в устном творчестве арабов. Например, «меч определил справедливость» - речь идет о приговоре. «Я смотрю на него и на меч», то есть речь идет о том, что тот, на кого обращен взор, так ненавидим, что вызывает только мысли о его убийстве.

\section{Литературно-мифологические сюжетные архетипы}

С целью наиболее полного представления об архетипах насилия, мира и милосердия в арабской мифологии и генезисе ислама мы предпринимаем попытку реконструировать литературно-мифологические сюжетные архетипы [Мелетинский, 1994]. Для этого мы должны обратиться к анализу литературы и поэзии доисламской Аравии. Арабская литература своими корнями уходит в устное словесное творчество родоплеменных обществ Аравийского полуострова. Следует отметить тот факт, что в доисламской арабской литературе превалировала поэзия. Среди жанров последней наибольшее распространение получили: хиджа - посрамление врагов племени, фахр - бедуинское самовосхваление, сар - песнь мести, риса или марсия - похоронная элегия, насиб - любовная лирика и васф - описание, пейзажная лирика. Следует напомнить, что в древней и средневековой Аравии жанр поэзии был очень популярен, а поэты почитались как обладатели божественного дара. В арабских преданиях запечатлены имена около 125 поэтов конца V - 1-й половины VII столетия: Имру аль-Кайс (500-540), Тарафа (543-569), АльХарис ибн Хиллиза аль-Йашкури (ум. 570), Зухайр ибн Аби Сульма (ок. 530 - ок. 627), Антара ибн Шаддад аль-Абси (525-615) и другие. 
Исследователи древнеарабской литературы и словесности отмечают талантливость бедуинов-кочевников: «Умение слагать стихи-песни ценилось в бедуинском воине не меньше, чем храбрость на поле боя. Поэт занимал высокое положение в обществе: он был певцом племенной доблести, хранителем его героических традиций. Племя гордилось и дорожило поэтом, умевшим словом защитить его честь и ядовитым стихотворным поношением унизить врага» [Фильштинский, 1985, с. 36]. Можно сказать, что поэтический талант расценивался как ратное искусство: «Поэт-бедуин должен был не только уметь постоять за свое племя с оружием в руках, но и защитить его в поэтическом поединке. Резким и язвительным словом он мог на многие годы заклеймить врага, и позор нанесенного оскорбления, как и воинская слава, переходил от отца к сыну» [Фильштинский, 1985, с. 54].

Следует отметить, что доисламская поэзия бедуинов не склонна к описанию душевных переживаний и размышлений, поскольку ее центральным персонажем является бедуин-воин - решительный, безрассудный, не склонный к пустым размышлениям и не задумывающийся о последствиях. Он не похож на персонажей героических эпосов, но вместе с тем терпелив, вынослив, способен стойко сносить как невзгоды кочевого образа жизни, так и удары судьбы. Даже смерть, воспринимаемая как трагедия индивидуальным сознанием, для родового сознания была естественным и даже желательным процессом. Доисламские поэты являются выразителями родоплеменной этики и в своих стихах воспевают бедуинские доблести, такие как храбрость в битве, великодушие, стойкость к невзгодам кочевой жизни.

Нельзя не упомянуть категорию древнеарабских поэтов, которые средневековой традицией были отнесены к так называемым поэтам-бродягам. В своих стихах данные поэты воспевают набеги, в которых они сами принимали участие. Среди данной категории поэтов особо выделяются аш-Шанфара (умер в первом десятилетии VI в.) и Тааббата Шарран (VI в.). Оба поэта воспевают доблести бедуинского родоплеменного общества, носителями которых они сами являлись. В поэме под названием «Лямийя» («Песня пустыни») аш-Шанфар описывает жизнь изгнанника в аравийской пустыне, как он стойко переносит тяготы жизни, а также набеги на кочевья бедуинов и оседлого населения. Поэт всячески превозносит жизнь кочевника-воина, друзьями которого являются только храброе сердце, обнаженный меч и длинный лук [Крачковский, 1955-1956].

Истинное имя Тааббаты Шарран - Сабит ибн Джабир. Прозвище, под которым он вошел в историю древнеарабской словесности, означает «носящий под мышкой зло», поскольку имел привычку таким образом носить меч. Как и аш-Шанфар, он прославился не только своими стихами, но и набегами на кочевья. Как свидетельствую его стихи, он соблюдал неписаный закон чести бедуинов, то есть прибегал к убийству, только следуя закону кровной мести, и совершал набеги только на племена, которые находились в состоянии войны с племенем, которому он принадлежал. В других своих поэмах, написанных в родственном фахру жанре мадх (панегирик), он прославляет бедуинские доблести своих соплеменников.

Анализ творчества древнеарабских поэтов позволяет утверждать, что в их поэмах преобладают в основном жанры, которые прославляют бедуинские воинские доблести. В то же время необходимо отметить одну из важных черт бедуинской поэзии: поэтические произведения поэтов-бедуинов не являют собой пример оригинальной мысли, отражающей мир фантастических образов. Как раз напротив - их творчество есть реалистичное описание образа жизни бедуинских племен доисламской Аравии. Данная отличительная черта поэзии поэтов-бедуинов позволяет рассматривать их одновременно как историков своей эпохи. В творчестве бедуинских поэтов отразились не только традиции и обычаи бедуинских племен доисламской Аравии, но и период распада родовых связей.

В рамках рассматриваемой нами проблемы следует упомянуть бедуинского поэтамиротворца Зухайра ибн Аби Сульма (ок. 530 - ок. 627), творчество которого почиталось 
эталоном разумной умеренности и назидательности. Центральной темой поэзии Зухайра было содействовать установлению мира между родственными племенами абс и зубьян, которые вели многолетнюю ожесточенную войну из-за пастбищных угодий и источников воды. В частности, особое место в творчестве Зухайра занимает поэма, в которой прославляются не достоинства племенной знати и доблести воинов, а его соплеменникимиротворцы Харим и аль-Харис, способствовавшие установлению мира между племенами [Фильштинский, 1985, с. 88]. Хвалебные строки в адрес Харима и аль-Хариса дополняются осуждением войн, призывами стремиться к миру, прощать дурные поступки.

\section{Жанровые особенности доисламской арабской литературы}

Согласно исследованию истории арабской литературы отечественного востоковеда-арабиста И.М. Фильштинского, доисламская Аравия не создала разработанного мифологического комплекса. Данный пробел заполнили дошедшие до наших дней предания, повествующие о многочисленных кровопролитных конфликтах меду арабскими племенами и племенными союзами. Представляющие собой довольно широкий пласт, данные предания открывают современным исследователям довольно подробную информацию об общественно-политической ситуации древней Аравии. Целью этих своего рода исторических хроник было сохранение для будущих поколений сведений о героических событиях прошлого и традиционных племенных обычаев и устоев. Данный комплекс преданий служит ценным источником, дающим наиболее полное представление о политической ситуации, быте и нравах жителей доисламской Аравии.

Следует отметить, что поэзия была в большей степени распространена среди бедуинов-кочевников, в то время как проза получила наибольшее распространение среди оседлых племен южных и восточных областей Аравийского полуострова. Отсутствие практически до времени появления ислама в арабской литературе художественной прозы компенсировалось наличием пословиц, поговорок, а также прозаической речи (хитаб или $x y m \sigma a)$. Вот какое определение хутба дает в своем энциклопедическом словаре «Китабул-камус» средневековый исследователь арабской лексики аль-Фирузабади (ум. 1414): «образная прозаическая речь, написанная, как правило, рифмованной ритмизованной прозой (садж), которая произносится при большом собрании людей красноречивым человеком с целью повлиять на слушателей, убедить их в чем-либо, призвать к каким-либо действиям или же просто развлечь» [цит. по: Гаффорова, 2015, с. 92].

В средневековой Аравии, находящейся в сложной общественной и политической ситуации, усугубляющейся непрекращающимися межплеменными конфликтами и междоусобными войнами, призванием как поэта, так и оратора была защита племени при помощи искусного слога. Разница заключалась лишь в том, что поэт был призван прославлять (свое племя) и порицать (врагов племени), тогда как призванием оратора было примирять и убеждать. Не случайно, что с утратой чувств племенного патриотизма среди основной массы поэтов, ораторы заполнили эту нишу и заняли достойное место в общественной и политической жизни средневековой Аравии.

Основные виды хутбы сложились в доисламский период и в последующем получили детальную проработку и нашли широкое применение в период правления четырех праведных халифов. К числу основных разновидностей доисламской прозаической речи относятся следующие: «1. Политическое красноречие (ал-хитаба ас-сийасийа): а) военная речь (ал-хутба ал-харбиййа); б) речи послов при исполнении дипломатической миссии (хутаб ал-вуфуд); в) речи, призывающие к миру (хутаб-ас-сулх). 2. Общественное красноречие (ал-хитаба ал-иджтима'иййа): а) речи, произносимые на торжествах бракосочетания (хутаб ан-никах); б) словесные состязания в целях самовосхваления (муфахара или 
мунафара); в) речи, выражающие соболезнование (хутаб ат-та'зиййа); г) речи, имеющие цель примирить враждующие стороны (ислах зат ал-бейн); д) завещательные речи (васайа). 3. Религиозное красноречие: а) религиозные проповеди (хутаб диниййа); б) рифмованная проза кахинов (садж' ал-куххан)» [Гаффорова, 2015, с. 94]. Таким образом, художественные особенности доисламской хутбы свидетельствуют о том, что она представляет собой особый тип арабской доисламской словесности, связанный с самыми злободневными проблемами политической, социальной и идейно-религиозной жизни арабов эпохи джахилийи.

«Мифологическое» насилие, практикуемое в среде аравийских племен доисламской эпохи (джахилийи), сменяется нравственно-правовым насилием теократического государства с его интуициями божественного закона (шариата) и идеи божественной справедливости. Заключенные в пространство халифата, они становятся координатами движения энергии насилия. От оппозиции естественного и неестественного, силы и насилия, справедливого и несправедливого практики насилия в следующую эпоху оформляются в религиозно-нравственное принуждение. Последнее, в свою очередь, трансформируется в политическое насилие, которое в своих ранних формах раскрывается в концептах джихада, а позднее - исламской революции [Борисов, 2013].

\section{Заключение}

Подводя итог, следует отметить, что архетипы насилия, мира и милосердия, сформированные арабской мифологией, нашли свое отражение в доисламской поэзии и прозе, прославлявших племенной патриотизм доисламских аравийских племен и ценности родоплеменного общества. Исламская теология, ориентированная на универсализм религии ислама, восприняла литературно-мифологические сюжетные архетипы доисламской поэзии и прозы и переработала их в соответствии с потребностями новой монотеистической религии, выходящей далеко за рамки этики племенного патриотизма. Перенесенные на почву теократического государства, идеологемы насилия, мира и милосердия получают статус религиозно-нравственного принуждения, не устраняющего насилие, но ограничивающего его рамками религиозно-правовых норм ислама.

\section{Список литературы}

1. Борисов С.Н. 2013. Феномен насилия в культурно-антропологических практиках и философской антропологии. Белгород, ИД «Белгород» НИУ «БелГУ», 252 с.

2. Гаффорова У.А. 2015. Особенности арабской средневековой прозы (хитаба) в доисламский период. Ученые записки, 4 (45): 92-96.

3. Грюнебаум Г.Э. фон 1988. Классический ислам. Очерк истории, 600-1258. М., Наука, 216 с.

4. Грязневич П. А. 1984. Проблемы изучения истории возникновения ислама. В кн.: Ислам. Религия, общество, государство. Отв. редакторы П.А. Грязневич и С.М. Прозоров. М., Наука: 5-18.

5. Крачковский И.Ю. 1955-1960. Избранные сочинения в 6 т. Т. 2. Арабская средневековая художественная литература (поэзия и проза). М.-Л., Издательство Академии наук СССР, 712 с.

6. Массе А. 2007. Ислам: Очерк истории. М., Крафт+, 200 с.

7. Матвеев К.П. 2005. История ислама. М., АСТ: Восток-Запад, 254 с.

8. Мелетинский Е.М. 1994. О литературных архетипах. М., Российский государственный гуманитарный университет, 136 с.

9. Мифологический словарь. 1991. Гл. ред. Е.М. Мелетинский. М., Сов. энцикл., 736 с.

10. Пиотровский М.Б. 1984. Пророческое движение в Аравии VII в. В кн.: Ислам. Религия, общество, государство. М., Наука: 19-27.

11. Резван Е.А. 1984. Адам и бану адам в Коране (к истории понятий «первочеловек» и «первочеловечество»). В кн.: Ислам. Религия, общество, государство. М., Наука: 59-68. 
12. Резван Е.А. 1984. Коран и доисламская культура (проблема методики изучения). В кн.: Ислам. Религия, общество, государство. М., Наука: 44-58.

13. Уотт У.М. 2007. Мухаммад в Медине. М.-СПб., ДИЛЯ, 480 с.

14. Фильштинский И.М. 1977. Арабская литература в средние века. Т. 1. Словесное искусство арабов в древности и раннем Средневековье. М., Восточная литература, $291 \mathrm{c}$.

15. Фильштинский И.М. 1985. История арабской литературы V - начало Х века. Отв. ред. Б.Я. Шидфар. М., Главная редакция восточной литературы, 531 с.

16. Шифман И.Ш. 1984. О некоторых установлениях раннего ислама. В кн.: Ислам. Религия, общество, государство. М., Наука: 36-43.

17. Юнг К. Г. 1991. Архетип и символ. М., Ренессанс, 304 с.

18. Peters F. E. 1994. Muhammad and the origins of Islam. New York, State University of New York press, $339 \mathrm{p}$.

\section{References}

1. Borisov S.N. 2013. Fenomen nasiliya v kul'turno-antropologicheskih praktikah i filosofskoj antropologii. [The phenomenon of violence in cultural and anthropological practices and philosophical anthropology]. Belgorod, ID «Belgorod» NIU «BelGU», 252 p.

2. Gafforova U.A. 2015. The features of medieval Arabic prose (Hitba) in pre-Islamic period. Scinentific Notes. Seriya gumanitarno-obshchestvennyh nauk, 4 (45): 92-96.

3. Gryaznevich P.A. 1984. Problemy izucheniya istorii vozniknoveniya islama. [Problems of studying the history of the emergence of Islam]. In: Islam. Religiya, obshchestvo, gosudarstvo. [Religion, society, state]. Editors P.A. Gryaznevich and S.M. Prozorov. M., Publ. Nauka: 5-18.

4. Gryunebaum G.E. fon 1988. Klassicheskij islam. Ocherk istorii, 600-1258. [Classical Islam. History Essay, 600-1258]. M., Publ. Nauka, 216 p.

5. Krachkovskij I.YU. 1956. Izbrannye sochineniya. [Selected works]. In 6 vols. Vol. 2. Arabskaya srednevekovaya khudozhestvennaya literatura (poehziya i proza). [Arabic medieval fiction (poetry and prose)]. M.-L., Publ. Akademii nauk SSSR, 712 p.

6. Masse A. 2007. Islam: Ocherk istorii. [Islam: An Outline of History] M., Publ. Kraft+, 200 p.

7. Matveev K.P. 2005. Istoriya islama. [History of Islam]. M., AST: Vostok-Zapad, 254 p.

8. Meletinskij E.M. 1994. O literaturnyh arhetipah. [About literary archetypes] M., Publ. Rossijskij gosudarstvennyj gumanitarnyj universitet, $136 \mathrm{p}$.

9. Mifologicheskij slovar'. [Mythological Dictionary] 1991. Ed. E.M. Meletinskij. M., Publ. Sov. encikl., $736 \mathrm{p}$.

10. Piotrovskij M. B. 1984. Prorocheskoe dvizhenie v Aravii VII v. [The Prophetic Movement in seventh-century Arabia]. In: Islam. Religiya, obshchestvo, gosudarstvo. [Religion, society, state]. M., Publ. Nauka: 19-27.

11. Rezvan E. A. 1984. Adam i banu adam v Korane (k istorii ponyatij «pervochelovek» i «pervochelovechestvo»). [Adam and Banu Adam in the Quran (on the history of the concepts of "first man" and "first manhood")]. In: Islam. Religiya, obshchestvo, gosudarstvo. [Religion, society, state]. M., Publ. Nauka: 59-68.

12. Rezvan E. A. 1984. Koran i doislamskaya kul'tura (problema metodiki izucheniya). [The Quran and pre-Islamic culture (the problem of the methodology of study)]. In: Islam. Religiya, obshchestvo, gosudarstvo. [Religion, society, state]. M., Publ. Nauka: 44-58.

13. Uott U. M. 2007. Muhammad v Medine. [Muhammad in Medina] SPb., Publ. DILYA, 480 p.

14. Fil'shtinskij I. M. 1977. Arabskaya literatura v srednie veka. [Arabic literature in the Middle Ages]. Vol. 1. Slovesnoe iskusstvo arabov v drevnosti i rannem Srednevekov'e. [The verbal art of the Arabs in antiquity and the early Middle Ages]. M., Publ. Vostochnaya literatura, $291 \mathrm{p}$.

15. Fil'shtinskij I. M. 1985. Istoriya arabskoj literatury V - nachalo X veka. [History of Arabic literature V - the beginning of the X century] Ed. B.YA. SHidfar. M., Publ. The Main editorial office of Oriental Literature, $531 \mathrm{p}$. 
16. SHifman I. SH. 1984. O nekotoryh ustanovleniyah rannego islama. [About some of the institutions of early Islam]. In: Islam. Religiya, obshchestvo, gosudarstvo. [Religion, society, state]. M., Publ. Nauka: 36-43.

17. Yung K.G. 1991. Arhetip i simvol. [Archetype and symbol]. M., Publ. Renessans, 304 p.

18. Peters F.E. 1994. Muhammad and the origins of Islam. New York, State University of New York press, $339 \mathrm{p}$.

Конфликт интересов: о потенциальном конфликте интересов не сообщалось.

Conflict of interest: no potential conflict of interest related to this article was reported.

\section{ИНФОРМАЦИЯ ОБ АВТОРАХ}

Борисовский Андрей Владимирович, аспирант кафедры философии, культурологии, науковедения Белгородского государственного института искусств и культуры, г. Белгород, Россия

Резник Сергей Васильевич, кандидат философских наук, доцент кафедры философии и теологии Белгородского государственного национального исследовательского университета, г. Белгород, Россия

\section{INFORMATION ABOUT THE AUTHORS}

Andrey V. Borisovsky, Postgraduate student at the Department of Philosophy, Cultural Studies and Science, Belgorod State Institute of Arts and Culture, Belgorod, Russia

Sergey V. Reznik, Candidate of Philosophical Sciences, Associate Professor of the Department of Philosophy and Theology, Belgorod National Research University, Belgorod, Russia 